УДК 349.2

https://doi.org/10.34142/23121661.2021.34.04

orcid. org/0000-0003-2727-5357

(C) Новіков Д.О., 2021

orcid. org/0000-0003-4945-9157

(C) Григор'єва I.В., 2021

Д. О. Новіков, І. В. Григор'єва

\title{
ВЗАЄМОЗВ'ЯЗОК СОЦІАЛЬНОЇ ФУНКЦІЇ ТРУДОВОГО ПРАВА ТА СОЦІАЛЬНОГО ДІАЛОГУ ПРИ РОЗВ'ЯЗАННІ ПРОБЛЕМ ГНУЧКОГО РЕГУЛЮВАННЯ ПРАЦІ
}

\author{
D. Novikov, I. Hryhorieva
}

\section{RELATIONSHIP BETWEEN THE SOCIAL FUNCTION OF LABOR LAW AND SOCIAL DIALOGUE IN SOLVING PROBLEMS OF FLEXIBLE LABOR REGULATION}

\begin{abstract}
Анотація. Автори вивчають взаємозв'язку соціальної функції трудового права та соціального діалогу при розв'язанні проблем гнучкого регулювання праці. Автори вказують, що соціальна функція трудового права у сучасних умовах залежить не лише від державного впливу на правове регулювання трудових відносин. На переконання авторів, сучасна держава у багатьох політико-економічних аспектах зацікавлена у послабленні соціальноправового захисту трудящих через необхідність одержання інвестицій та залучення іноземних компаній для створення виробництва. Відзначається, що трудове законодавство поступово набуває все більшої гнучкості, переносячи все більше питань, що стосуються умов праці, на договірний рівень. Автори вказують, що об'єктивним є те, що на індивідуальному договірному рівні працівникові, який залежить від необхідності отримання роботи, вкрай складно проявляти власну волю при взаємодії із роботодавцем. Автори підкреслюють, що одночасно підсилюється значення та підвищуються колективних договірних засобів регулювання трудових відносин, що вимагає належного рівня організованої солідарності трудящих. Авторами констатується, що солідарність у цьому сенсі представляє собою соціальну єдність індивідів поєднаних певною властивістю при усвідомленні необхідності такого поєднання для досягнення конкретної позитивної мети. Результатом солідарності має стати активне впровадження у практику соціального діалогу укладення міжнародних рамкових угод між транснаціональними корпораціями, державою та населенням, представленому спеціалізованими професійними спілками, зокрема, міжнародними. Автори зазначають, що на підставі укладення міжнародних рамкових угод реалізовуватиметься соціальна функція трудового права, котра тепер не будучи прив'язаною до держави та ії органів, означатиме дійсний баланс інтересів учасників трудових відносин. На думку авторів,
\end{abstract}


доцільною є розробка національної програми із підтримки профспілкового руху в Україні та колективного співробітництва $з$ міжнародними профспілками на 2021-2031 роки. Результатом цього співробітництва має стати збільшення кількості міжнародних рамкових угод, укладених з транснаціональними корпораціями.

Ключові слова: соціальна функція, трудове право, соціальний діалог, солідарність, гнучкість.

Аннотация. Авторы изучают взаимосвязь социальной функции трудового права и социального диалога при решении проблем гибкого регулирования труда. Авторы указывают, что социальная функция трудового права в современных условиях зависит не только от государственного влияния на правовое регулирование трудовых отношений. По мнению авторов, современное государство во многих политико-экономических аспектах заинтересовано в ослаблении социально-правовой защиты трудящихся из-за необходимости получения инвестиций и привлечения иностранных компаний для создания производства. Отмечается, что трудовое законодательство постепенно приобретает все большую гибкость, перенося все больше вопросов, касающихся условий труда, на договорной уровень. Авторы указывают, что объективным является то, что на индивидуальном договорном уровне работнику, зависящему от необходимости получения работы, крайне сложно проявлять собственную волю при взаимодействии с работодателем. Авторы подчеркивают, что одновременно усиливается значение и повышаются коллективных договорных средств регулирования трудовых отношений, что требует надлежащего уровня организованной солидарности трудящихся. Авторами констатируется, что солидарность в этом смысле представляет собой социальное единство индивидов объединенных определенным свойством при осознании необходимости такого сочетания для достижения конкретной позитивной цели. Результатом солидарности должно стать активное внедрение в практику социального диалога заключения рамочных соглашений между транснациональными корпорациями, государством и населением, представленном специализированными профессиональными союзами, в частности, международными. Авторы отмечают, что на основании заключения рамочных соглашений реализовываться социальная функция трудового права, которая теперь, не будучи привязанной к государству и его органам, будет означать действительный баланс интересов участников трудовых отношений. По мнению авторов, целесообразной является разработка национальной программы по поддержке профсоюзного движения в Украине и коллективного сотрудничества с международными профсоюзами на 2021-2031 годы. Результатом этого сотрудничества должно стать увеличение количества международных рамочных соглашений, заключенных с транснациональными корпорациями.

Ключевые слова: социальная функция, трудовое право, социальный диалог, солидарность, гибкость.

Abstract. The authors study the relationship between the social function of labor law and social dialogue in solving problems of flexible labor regulation. The authors point out that the social function of labor law in modern conditions depends not only on state influence on the legal regulation of labor relations. According to the authors, the modern state in many political and economic aspects is interested in weakening the socio-legal protection of workers through the need to attract investment and attract foreign companies to create production. It is noted that labor legislation is gradually becoming more flexible, shifting more and more issues related to working conditions to the contractual level. The authors point out that it is objective that at the individual 
contractual level it is extremely difficult for an employee, who depends on the need to get a job, to show his own will when interacting with the employer. The authors emphasize that at the same time the importance of collective bargaining means of regulating labor relations is increasing, which requires an appropriate level of organized solidarity of workers. The authors state that solidarity in this sense is a social unity of individuals united by a certain property, realizing the need for such a combination to achieve a specific positive goal. The result of solidarity should be the active implementation in the practice of social dialogue of international framework agreements between transnational corporations, the state and the population, represented by specialized trade unions, in particular, international ones. The authors note that the conclusion of international framework agreements will implement the social function of labor law, which is now not tied to the state and its bodies, will establish a real balance of interests of participants in labor relations. According to the authors, it is advisable to develop a national program to support the trade union movement in Ukraine and collective cooperation with international trade unions for 2021-2031. The result of this cooperation should be an increase in the number of international framework agreements concluded with transnational corporations.

Key words: social function, labor law, social dialogue, solidarity, flexibility.

Постановка проблеми. Соціальний діалог в умовах ринкових відносин $є$ ключовим елементом забезпечення балансу інтересів антагоністів у соціальноекономічних відносинах, що $є$ однією з основних характеристик соціальної функції трудового права. Впливаючи на розподіл створеного виробничою сферою та сферою послуг суспільного продукту, соціальний діалог спрямовує свої сили на досягнення загального компромісу інтересів між працівниками, роботодавцями та державою і відповідно виконує провідне соціальне призначення - зберігає необхідний консенсус між учасниками трудових відносин. Це підтверджується й згідно преамбули Закону України «Про соціальний діалог в Україні», де вказується, що оформлений угодою компроміс має кінцевою метою «забезпечення підвищення рівня і якості життя громадян, соціальної стабільності в суспільстві» [1]. Особливо важливим стає соціальний діалог та закладена в його основу соціальна функція трудового права в умовах, коли вітчизняне законодавство поступово реформується у бік більшої «гнучкості», а іноді й повноцінного дерегулювання, трудових відносин. У таких умовах акценти соціальний компроміс хитається у бік фактично сильнішої сторони трудових відносин. Відповідно, виконання соціальної функції трудового права стає можливим переважно завдяки колективним інституціолізованим зусиллям працівників, вираженим у формі соціального діалогу.

Аналіз останніх досліджень $і$ публікацій. У вітчизняній науці трудового права соціальна функція трудового права вивчається із різних точок дослідницького дотику. О.Є. Костюченко [2] розглядає соціальну функцію трудового права з аксіологічних позицій; А. Апанасенко [3] - у контексті цивілізаційного розвитку трудового права як соціальної галузі права, котра формулює вимоги соціального характеру щодо захисту прав і зменшення експлуатації праці 
працівників; Л.П. Шумна, О.Г. Огородник та Н.М. Свириденко [4] - через призму формування оновленого підходу до побудови взаємодії між роботодавцями та працівниками в умовах діджиталізації праці. Разом із тим сучасна трудоправова наука оминає своєю увагою питання важливості соціального діалогу для впровадження цілей соціальної функції трудового права.

Мета дослідження. Автори мають на меті розкрити питання взаємозв'язку соціальної функції трудового права та соціального діалогу при розв’язанні проблем гнучкого регулювання праці.

Виклад основного матеріалу статmі. Французький соціолог П. Бурд’є свого часу вказував на те, що «перед обличчям нових форм експлуатації, яким особливо сприяли скасування державного регулювання та розвиток тимчасової зайнятості, традиційні форми дій профспілок видаються неадекватними, руйнуються основи колишньої солідарності, а розчарування, яке виникає 3 цього, іде рука об руку із занепадом бойового духу та спадом політичної активності» [5, с. 628]. За умов ліберального підходу до регулювання трудових відносин праця стала «гнучкою», що повсякденною мовою це означає, що роботодавцю стає легше звільняти працівників, солідарні ж - і тому ефективні - дії профспілок із захисту несправедливо звільнених усе більше виглядають як нездійсненна мрія. Як зазначає 3. Бауман, «"гнучкість” означає, що стара життєва стратегія, у руслі якої сили й час вкладалися у підвищення кваліфікації, у досягнення статусу фахівця, що дозволяє сподіватися на постійне одержання із цього відсотків, стає усе більш безглуздою, i, таким чином, тепер зник найпоширеніший у свій час варіант розумного вибору людей, що бажають у житті сталості» [6, с. 222], а «місце роботи сприймається як наметовий табір, де людина зупинилась лише на кілька днів і може покинути його в будь-який момент, а не як загальне постійне місце проживання, де вона збирається непохитно переносити неприємності та терпляче виробляти прийнятні правила гуртожитку» [7, с. 147].

Як результат даних процесів, відбувається руйнування «культури солідарності» під впливом тих тенденцій, які звичайно позначаються поняттям «індивідуалізація». Індивідуалізація означає, що окремі індивіди намагаються вийти $з$ первісного соціального та територіального середовища i власноруч визначати свій життєвий шлях і власний стиль життя. Зростаюча соціальна та просторова мобільність людей, усвідомлення того, що вони самі $є$ архітекторами свого життя, виключають виконання багатьох соціальних зобов’язань. Як наслідок, зменшується схильність виконувати зобов'язання не тільки стосовно родини та місцевих спільнот, але й до системи державного соціального забезпечення. Однак індивідуалізм, народжений першочергово у нерівних умовах, не може запропонувати нічого іншого окрім розчарування, тому що пропону- 
ючи вільний вибір індивіду, він обтяжує шляхи досягнення реалізації цього вибору обмеженням ресурсів для його задоволення.

У ситуації «смерті старої солідарності» продуктивним видається варіант пошуку нових форм спільної організації у межах соціального діалогу з державою та глобальним капіталом, тобто тими, хто є відповідальними за теперішнє положення так званого прекаріату [8]. Т. Ю. Сідоріна зазначає, що «традиційно всі завдання демократичної соціальної держави на Заході вирішувалися за допомогою інституціалізації соціального контракту між державою та громадянським суспільством, а конкретно - між державою, роботодавцями, профспілками та суспільними асоціаціями і неурядовими організаціями. Ці відносини побудовані на принципі солідарності» [9, с. 173]. Відповідно, класичною основою досягнення солідарності є компроміс, тобто здатність всіх учасників соціального контракту жертвувати частиною своїх інтересів для раціонального досягнення їх базової частини, а також для досягнення суспільного блага, що припускає «економічне зростання, поліпшення добробуту всіх громадян, соціальну справедливість, соціальну участь, сприятливу моральну атмосферу, культурний i духовний розвиток, підтримку демократичних і гуманістичних цінностей, розвиток прав і свобод» [10]. Держава жертвує своїм всевладдям, оскільки свідомо бере на себе відповідальність за створення суспільства i бажає розділити тягар цієї відповідальності з роботодавцями, профспілками та громадськими організаціями. Роботодавці погоджуються підтримати принцип забезпечення повної або зайнятості, яка наближається до такої, в обмін на скорочення вимог профспілок про підвищення заробітної плати. Профспілки пом'якшують цю вимогу заради досягнення повної зайнятості. Громадські організації пом'якшують критику уряду та виражають солідарність із його політикою заради досягнення загального добра. Держава співробітничає з ними заради зменшення тягаря власної відповідальності.

Водночас принцип солідарності в умовах глобалізації у чистому вигляді провести неможливо, але його може замінити принцип взаємної відповідальності держави та суспільства. Однак це означає, що люди будуть нести більший фінансовий тягар, але держава гарантує захист ряду галузей соціальної сфери від свавілля ринку. Не можна не погодитись із З. Бауманом, що «"спільність" - найкоротший шлях до духовного єднання та до тієї близькості, котра навряд чи коли-небудь має місце в "реальному житті": єднання повної подібності, типу “ми всі однакові”; єднання, яке не потрібно “шукати”, а яке "дано”, і дано задовго до того, як початі які-небудь зусилля, щоб викликати його» [7, с. 150]. Як вказує Ю. Хабермас, «сучасні суспільства володіють трьома ресурсами, завдяки яким вони можуть задовольняти свою потребу в управлінні: грошима, владою та солідарністю. Між сферами їх впливу слід встановити нову рівновагу. Необхідно затвердити соціально-інтегративну 
владу солідарності проти обох інших владних ресурсів - грошей і адміністративної влади» [11, с. 108]. Тому, на думку Ю. Хабермаса, «окремі держави повинні відчутно для внутрішньої політики втягуватися в зобов'язуючі процеси кооперації космополітичним чином зобов'язуючого співтовариства держав. Тому вирішальне питання полягає у тому, чи зможе в громадянських суспільствах і у політичної громадськості єдиної системи, що займає території багатьох країн, скластись свідомість необхідності космополітичної солідарності» [11, с. 231].

Однією 3 форм прояву космополітичної солідарності та відповідного інтернаціонального соціального діалогу за умов глобалізації має стати міжнародна рамкова угода тобто колективний договір, який охоплює головним чином працівників підприємств ТНК. Цей договір фіксує в уніфікованому вигляді умови праці у філіях і на материнських підприємствах міжнародної корпорації, а також положення, що стосуються географічного та регіонального розподілу інвестицій і виробництва (відкриття та закриття, реконструкція підприємств). Прикладом такої міжнародної рамкової угоди може служити угода між профспілками та керівництвом ТНК «Главербел Гласі компані», що охопила підприємства цієї корпорації у Франції, Бельгіі, Австрії, Італії, ФРН [12, с. 251]. Укладення міжнародних рамкових угод вигідно працівникам, адже перешкоджає керівництву ТНК використовувати у своїх інтересах міжнародну диференціацію заробітної плати, умов праці, конкуренцію між працівниками різних країн, а також більшу мобільність капіталів, чим робочої сили.

Висновки. Соціальна функція трудового права у сучасних умовах залежить не лише від державного впливу на правове регулювання трудових відносин. Адже сучасна держава у багатьох політико-економічних аспектах зацікавлена у послабленні соціально-правового захисту трудящих через необхідність одержання інвестицій та залучення іноземних компаній для створення виробництва. Відповідно, трудове законодавство поступово набуває все більшої гнучкості, переносячи все більше питань, що стосуються умов праці, на договірний рівень. Об'єктивним є те, що на індивідуальному договірному рівні працівникові, який залежить від необхідності отримання роботи, вкрай складно проявляти власну волю при взаємодії із роботодавцем. Водночас підсилюється значення та підвищуються колективних договірних засобів регулювання трудових відносин, що вимагає належного рівня організованої солідарності трудящих. Солідарність у цьому сенсі представляє собою соціальну єдність індивідів поєднаних певною властивістю при усвідомленні необхідності такого поєднання для досягнення конкретної позитивної мети. Результатом солідарності має стати активне впровадження у практику соціального діалогу укладення міжнародних рамкових угод між транснаціональними корпораціями, державою та населенням, представленому спеціалізованими професійними спілками, 
зокрема, міжнародними. На підставі укладення міжнародних рамкових угод реалізовуватиметься соціальна функція трудового права, котра тепер не будучи прив'язаною до держави та іiі органів, позначатиме дійсний баланс інтересів учасників трудових відносин. У даному аспекті доцільною $є$ розробка національної програми із підтримки профспілкового руху в Україні та колективного співробітництва 3 міжнародними профспілками на 2021-2031 роки. Результатом цього співробітництва має стати збільшення кількості міжнародних рамкових угод, укладених з транснаціональними корпораціями. Для посилення правового фундаменту розвитку міжнародного соціального діалогу до Закону України «Про соціальний діалог» необхідно додати відповідний розділ, присвячений четвертому (міжнародному) рівню соціального діалогу.

\section{Література}

1. Про соціальний діалог в Україні: Закон України від 23 грудня 2010 року № 2862VI. Відомості Верховної Ради України. 2011. № 28. ст. 255; 2. Костюченко О.Є. Соціальна цінність трудового права. Економічна теорія та право. 2018. Вип. 1 (32). С. 137-148; 3. Апанасенко А. Соціальна функція трудового права. Підприємництво, господарство $i$ право. 2012. Вип. 12. С. 69-71; 4. Шумна Л.П., Огородник О.Г., Свириденко Н.М. Новий діапазон соціальної функції трудового права. Науковий вісник Сіверщини. Серія: Право. 2018. № 3. C. 46-55; 5. La Misere du monde / ed. Pierre Bourdieu. Paris: Seuil, 1993. 947 p.; 6. Бауман 3. Индивидуализированное общество / Пер. с англ. под ред. В.Л. Иноземцева. М.: Логос, 2005. 390 с.; 7. Бауман 3. Текучая современность / Пер. с англ. под ред. Ю. В. Асочакова. СПб.: Питер, 2008. 240 с.; 8. Новіков Д.О. Pluralitas non est poneda sine necessiate або місце теорій прекаріату у науці трудового права. Науковий вісник Ужгородського національного університету. Серія «Право». 2015. Вип. 34. Т. 2. С. 22-26; 9. Сидорина Т.Ю. Два века социальной политики. М.: Российск. гос. гума-нит. ун-т, 2005. 442 с.; 10. Мацонаушили Т. Проблема перестройки государства в Западной Европе. Pro et Contra. 2001. Т. 6. № 3; 12. Хабермас Ю. Политические работы. М.: Праксис, 2005. 368 с. 13. Киселев И.Я. Сравнительное и международное трудовое право: Учебник для вузов. М.: Дело, 1999. 728 с. 